\title{
NOWE PERSPEKTYWY ROZWOJU W ROSYJSKO-CHIŃSKICH RELACJACH GOSPODARCZYCH
}

Spadek cen ropy oraz nałożenie sankcji ekonomicznych na Federację Rosyjską przez Stany Zjednoczone i państwa europejskie po wydarzeniach na Ukrainie w 2014 r. spowodowały ostry kryzys w gospodarce rosyjskiej. Sankcje wpłynęły nie tylko na przemiany gospodarcze w Rosji i na świecie, ale również na przemiany w stosunkach międzynarodowych. Większość analityków rynkowych jest zgodna, że sankcje w stosunku do Federacji Rosyjskiej będą tylko wpływać na zacieśnianie współpracy Moskwy z państwami niezachodnimi, w tym z Chińską Republiką Ludową. Celem niniejszego artykułu jest zwrócenie uwagi na pogłębianie wzajemnych stosunków między Rosja a Chinami oraz próba odpowiedzi na pytanie, jak będzie wyglądać dalsza perspektywa wzajemnych relacji gospodarczych między tymi krajami.

Obecnie coraz częściej zwraca się uwage na wszelkie wspólne działania podejmowane przez Chiny i Rosję ze względu na mocarstwowy charakter obu państw oraz potencjał gospodarczy i militarny. Należy pamiętać, że oba kraje odgrywaja kluczową rolę w geopolitycznym wyścigu mocarstw. Rosja jest największym krajem pod względem terytorialnym (ponad $17 \mathrm{mln} \mathrm{km}^{2}$ ), Chiny zaś państwem najbardziej zaludnionym (ponad 1,3 mld osób). Ponadto ze względu na fakt, że Rosja jest jednym z kluczowych eksporterów surowców, a Chiny jednym z największych importerów, można zauważyć wspólnotę interesów ${ }^{1}$.

Jeszcze w 2013 r. rosyjski koncern petrochemiczny Rosnieft ${ }^{2}$ i największe chińskie przedsiębiorstwo China National Petroleum Corporation ${ }^{3}$ podpisały kontrakt w ramach długofalowej strategii Federacji Rosyjskiej na dostawę do Chin $365 \mathrm{mln}$ ton ropy naftowej w ciagu 25 lat. Trasa dostaw ropy naftowej przebiega przez ropociagi Eastern Siberia - Pacific Ocean. Oprócz ropociąu ESPO koncern Rosnieft

\footnotetext{
1 M. Lubina, Niedźniedź, w cieniu smoka: Rosja - Chiny 1991-2014, Kraków 2014, s. 381.

2 Rosnieft (Роснефть) - rosyjski państwowy koncern działający w branży petrochemicznej od 1993 r. Siedziba znajduje się w Moskwie. Głównym akcjonariuszem spółki jest Rząd Federacji Rosyjskiej posiadający 75,16\% akcji, 15\% akcji znajduje się wolnym obrocie.

3 China National Petroleum Corporation (CNPC) - chińskie przedsiębiorstwo państwowe zajmujące się handlem oraz wydobyciem ropy naftowej i gazu ziemnego, założone w $1988 \mathrm{r}$. Siedziba znajduje się w Pekinie. Właścicielem jest Rząd ChRL.
} 
dostarcza ropę do Chin na mocy umowy międzynarodowej ropociagiem Atas - Alashankou (tranzytem przez Kazachstan), Skoworodino - Mohe i z portu Koźmino 4 . Wiele porozumień między Rosją a Chinami przyczyniło się do tego, że w 2016 r. Rosja stała się głównym dostawcą ropy do Chin (52,5 mln ton), wyprzedzając Arabię Saudyjską (51 mln ton). Eksport ropy z Rosji jest tańszy niż z krajów Zatoki Arabskiej $i$ jest korzystniejszy pod względem jakości ${ }^{5}$. Na wykresie 1 zilustrowano, jak wyglądał eksport ropy i produktów ropopochodnych z Rosji do Chin w latach 2013-2017.

Jak wynika z wykresu 1, w latach 2016-2017 nastapił wzrost dostaw ropy i produktów ropopochodnych o $13 \mathrm{mln}$ ton. Przewiduje się, że wartość dostaw w 2018 r. będzie jeszcze większa, a to za sprawą drugiej linii ropociagu na odcinku między Mohe i Daqing, oddanej do użytku na początku stycznia $2018 \mathrm{r}^{6}$

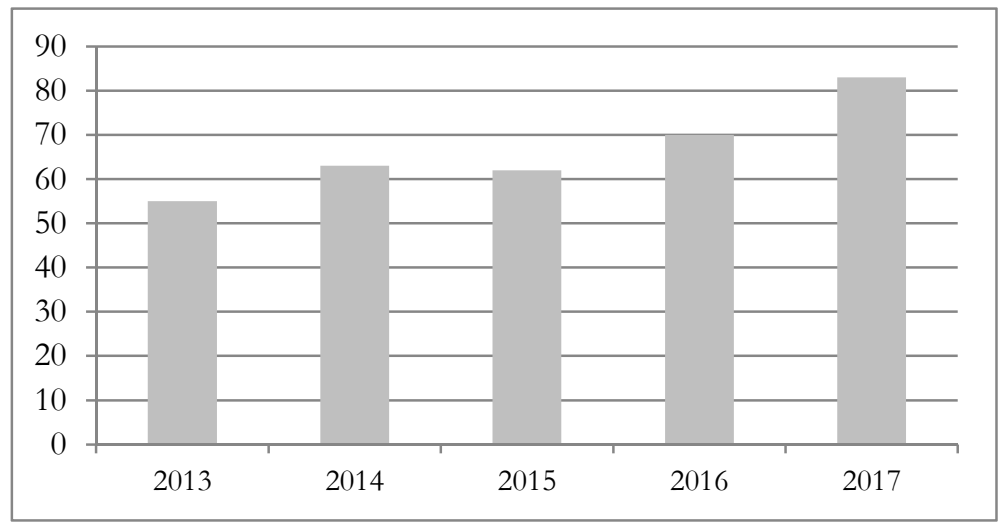

Wykres 1. Eksport ropy i produktów ropopochodnych z Rosji do Chin (mln ton)

Źródło: Opracowanie własne na podstawie Эксnорm из Poсcuи в Kumaŭ, http://ru-stat.com/date-Y2013-2017/RU/export/CN/0527 (dostęp: 20.03.2018).

W przyszłej perspektywie będą rosnąć również dostawy gazu do Chin pod postacia gazu ziemnego w ciekłym stanie skupienia (LNG). W latach 2013-2017 eksportowano z Rosji do Chin towary z grupy skroplonego gazu ziemnego o łącznej masie 853 tys. ton i pojemności 1,9 $\mathrm{mln} \mathrm{m}^{3}$, a ich koszt wyniósł $105 \mathrm{mln}$ USD. W strukturze rosyjskiego eksportu według krajów (towary z grupy LNG) na pierw-

4 T. Sporek, Perspektymy rozwoju Federacji Rosyjskiej w dobie sankicii zagranicznych po wydarzeniach ukrainskich w 2014 roku [w:] Handel zagraniczny i biznes międzynarodowy we wspótczesnej gospodarce, red. M. Maciejewski, K. Wach, Kraków 2017, s. 273.

5 Г. Сталинская, Россия увеличит экспорт нефти в Китай, но в челом поставка за рубен по нефтеироводам в 2018 году снизится, https://www.vedomosti.ru/business/articles/2018/01/12/747646rossiya-uvelichit-eksport-nefti-kitai (dostęp: 20.03.2018).

6 Wiecej ropy naftowej z Rosji do Chin, http://nafta.wnp.pl/wiecej-ropy-naftowej-z-rosji-do-chin,314373_1_0_0.html (dostęp: 20.03.2018). 
szym miejscu znajduje się Japonia (81\%), a następnie Korea Południowa $(16 \%)$. Chiny dla Rosji są czwartym partnerem pod względem udziału, który wynosi $0,5 \%{ }^{7}$. Zwiększenie dostaw gazu ma nastapić dzięki podpisanej w maju 2014 r. umowie

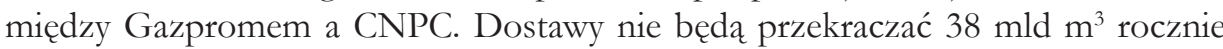
przez 30 lat od momentu ukończenia budowy gazociąu Siła Syberii - 1 (wschodni szlak), planowanego na rok 2020. Trwają również rozmowy na temat porozumienia o dostawach gazu przez szlak zachodni Siła Syberii $-2^{8}$.

Warto zauważyć, że ponad 50\% całego eksportu rosyjskiego do Chin składa się z dostaw źródeł energii. Jeszcze kilka lat temu dostawy ropy i gazu utrzymywały się na poziomie ponad 70\%. Spadek o 20 pp. dostaw źródeł energii w całym eksporcie, jest tłumaczony tym, że została zwiększona ilość dostarczanych towarów innych niż energetyczne 9 . O rozmiarach handlu i jego dynamice między Rosją a Chinami świadczą dane przedstawione w tabeli 1.

Tabela 1. Dynamika handlu zagranicznego między Federacją Rosyjską a ChRL (mln USD)

\begin{tabular}{|l|c|c|c|c|c|c|c|c|}
\hline & $\mathbf{2 0 1 0}$ & $\mathbf{2 0 1 1}$ & $\mathbf{2 0 1 2}$ & $\mathbf{2 0 1 3}$ & $\mathbf{2 0 1 4}$ & $\mathbf{2 0 1 5}$ & $\mathbf{2 0 1 6}$ & $\mathbf{2 0 1 7}$ \\
\hline $\begin{array}{l}\text { Obrót } \\
\text { towarowy }\end{array}$ & 59291 & 83232 & 87394 & 88799 & 88389 & 63556 & 66108 & 86964 \\
\hline Eksport & 20326 & 35030 & 35766 & 35625 & 37505 & 28605 & 28021 & 38922 \\
\hline Import & 38964 & 48202 & 51628 & 53173 & 50884 & 34950 & 38087 & 48042 \\
\hline Saldo & -18638 & -13172 & -15862 & -17548 & -13380 & -6345 & -10066 & -9120 \\
\hline
\end{tabular}

Źródło: Внешняя торговля России, http://russian-trade.com/reports-and-reviews/2018-03/ dinamika-torgovli-rossii-s-kitaem-v-2010-2017-godah/ (dostęp: 28.03.2018).

Maksymalna wartość obrotu handlowego po 2010 r. przypadała na lata 20112014. W 2014 r. Moskwa i Pekin sugerowały, że w 2015 r. wskaźniki te mogą przekroczyć nawet 100 mld USD. Nastapił jednak gwałtowny spadek obrotów o 28\% w 2015 r. W dużej mierze był on spowodowany spadkiem rosyjskiego rubla w grudniu 2014 r. Częściowo na spadek wartości rosyjskiej waluty wpłynęła sytuacja w Chinach, gdzie w 2015 r. całkowity handel zagraniczny Chin zmalał o 7\%, co z kolei można wyjaśnić licznymi problemami w rozwoju gospodarczym Państwa Środka. W 2016 r. nastapiło ożywienie, choć bardzo niewielkie (wzrost o 4\%), w handlu między obydwoma krajami. Dopiero w 2017 r. obroty ponownie znacznie wzrosły (o 24\% ${ }^{10}$.

7 Экспорт из России в Китай «газ природный сжиженный», http://ru-stat.com/date-Y2013-2017/ RU/export/CN/05271111 (dostęp: 27.03.2018).

8 P. Stępiński, Siła Syberii rośnie, a z. niq ryzyłko, http://biznesalert.pl/sila-syberii-chiny-rosja-gazprom/ (dostęp: 27.03.2018).

9 О. Самофалова, Торговля России с Китаем снова набирает обороты, https://vz.ru/economy/2017/2/10/857473.html (dostęp: 28.03.2018).

10 В. Катасанов, Российско-китайская торговля: Аолларовая зависимость остается, http://ruskline.ru/opp/2018/mart/16/rossijskokitajskaya_torgovlya_dollarovaya_zavisimost_ostaetsya/ (dostęp: 2.04.2018). 
Poprawa sytuacji w obrocie towarowym z Rosja jest tłumaczona uporządkowaniem polityki monetarnej Chin oraz optymalizacją mechanizmów kontrolnych i regulujących handel. Oczywiście wzrost importu z Rosji do Chin jest wspomagany spadkiem kursu juana w stosunku do dolara. Spadek cen ropy naftowej i dewaluacja rubla przyczyniły się do odkrycia nowych możliwości dla rosyjskich towarów na rynku chińskim. W rezultacie Rosja stała się konkurencyjną w sferze dostaw produkcji mechanicznej i elektronicznej. Ponadto do sukcesu rosyjskiego eksportu przyczynił się nie tylko słaby, ale jednocześnie stabilny rubel. Oprócz tego nastąpił spadek inflacji, a Bank Rosji potwierdził swoje zaangażowanie w politykę płynnego kursu walutowego. To pomogło przedsiębiorstwom, które zamierzały importować rosyjską produkcję lub planują wspólne projekty. Dodatkowo potrzeba było czasu, aby sformułować infrastrukturę, łańcuchy dostaw i wzmocnić więzi biznesowe między państwami ${ }^{11}$.

Nową dekadę relacji rosyjsko-chińskich charakteryzował głównie nacisk na surowce i geopolitykę surowcowa. Jednak przez ostatni rok rosyjski eksport towarów niesurowcowych i nieenergetycznych zwiększył się o 25\% (około 3,5 mld USD) ${ }^{12}$. W tabeli 2 przedstawiono 10 najpopularniejszych grup towarów eksportowanych przez Rosję do Chin.

Tabela 2. Eksport grup towarowych z Federacji Rosyjskiej do ChRL w 2016 i 2017 r. (mln USD)

\begin{tabular}{|c|l|r|r|}
\hline $\begin{array}{c}\text { Kod } \\
\text { towaru }\end{array}$ & \multicolumn{1}{|c|}{ Nazwa grupy towarowej } & $\mathbf{2 0 1 6}$ & $\mathbf{2 0 1 7}$ \\
\hline 44 & drewno i artykuły z nich; węgiel drzewny & 2593 & 3265 \\
\hline 84 & reaktory jądrowe, kotły, urządzenia mechaniczne, ich części & 1201 & 1564 \\
\hline 3 & ryby i skorupiaki, mięczaki i inne bezkręgowce wodne & 1033 & 1089 \\
\hline 26 & ruda, żużel i popiół & 769 & 1042 \\
\hline 47 & $\begin{array}{l}\text { masa drewna lub innych włóknistych materiałów celulozowych; } \\
\text { papier z recyklingu lub tektura (makulatura i odpady) }\end{array}$ & 708 & 791 \\
\hline 31 & nawozy & 748 & 667 \\
\hline 85 & $\begin{array}{l}\text { elektryczne maszyny i sprzęt, części do nich, sprzęt do nagrywania } \\
\text { dźwięku i odtwarzania dźwięku, sprzęt do nagrywania i odtwarzania } \\
\text { obrazów telewizyjnych i dźwięku, ich części i akcesoria }\end{array}$ & 184 & 626 \\
\hline 74 & miedź i artykuły z miedzi & 9 & 482 \\
\hline 29 & organiczne związki chemiczne & 195 & 303 \\
\hline 39 & tworzywa sztuczne i artykuły z nich & 178 & 282 \\
\hline
\end{tabular}

Źródło: Opracowanie własne na podstawie: Внещняя торговля Pоссии, http://russian-trade.com/reportsand-reviews/2018-03/dinamika-torgovli-rossii-s-kitaem-v-2010-2017-godah/ (dostęp: 2.04.2018).

11 О. Самофалова, Торговля России с Китаем...

12 Внешняя торговля России, http://russian-trade.com/reports-and-reviews/2018-03/dinamika-torgovli-rossii-s-kitaem-v-2010-2017-godah/ (dostęp: 2.04.2018). 
Przez ostatnie lata w Chinach pojawiło się wiele przedsiębiorstw, które wyposażone są w sprzęty z Rosji. Wśród niesurowcowego eksportu z Rosji do Chin główne miejsce zajmuje produkcja przemysłu maszynowego. Przykładowo Rosja aktywnie dostarcza turbiny gazowe, sprzęt o niskim tonażu dla LNG i inne maszyny wykorzystywane w przemyśle energetycznym. Do największych eksporterów należą Rosatom, Uralska Fabryka Turbin oraz korporacja budująca silniki „Power Machines”13.

Dodatkowo rośnie udział sektora rolnego w strukturze rosyjskiego eksportu do Chin. Przez najbliższe lata eksport produkcji rolnej do Chin będzie rósł, a to za sprawą aktywnie działającego systemu Rosyjskiego Centrum Eksportu ${ }^{14}$, który bada sytuację $\mathrm{w}$ regionach przygranicznych. Wskazuje on potencjalne punkty eksportowe i wspiera je na wszystkich etapach, aż do zawarcia kontraktu. Według danych Rosyjskiego Centrum Eksportu eksport towarów rolnych do Chin wyniósł 11\% w 2016 r., co oznacza wzrost o 8\% względem roku $2015^{15}$. Współpraca w dziedzinie żywności staje się ważnym obszarem wymiany dwustronnej. W szczególności przedstawiciele 17 rosyjskich firm, w tym: Longavita, Aleyka, Yanta, Beijing Soko International, Talina, Shanghai LiKa International i Uvelka, rozpoczęli aktywną współpracę w zakresie powołania Stowarzyszenia Rosyjskich Producentów Żywności Ekologicznej. Następnie przedsiębiorstwa te mają rozwinąć swoją działalność na rynku chińskim. Chiny wyrażaja zainteresowanie rosyjskimi wyrobami cukierniczymi, czekoladą i słodyczami, opracowywany jest plan projektu wspólnego rozlewu wody mineralnej. Ponadto chińscy inwestorzy wykazują zainteresowanie projektami budowy szklarni i uprawy soi w regionie Stawropola. W ramach Dni Prowincji Heilongjiang we Władywostoku (14-15 listopada 2016 r.) firmy rosyjskie i chińskie podpisały 14 umów dotyczących dostaw żywności, utworzenia centrum logistycznego do przechowywania ziarna oraz przetwórstwa owoców morza ${ }^{16}$.

Wiele porozumień podpisali w ciagu ostatnich kilku lat liderzy Federacji Rosyjskiej i ChRL, co wpłynęło na ożywienie w obrocie towarowym między państwami i ogólną współpracę gospodarczą. Najważniejszym wydarzeniem politycznym w ramach dwustronnej współpracy była oficjalna wizyta Władimira Putina w Chinach

13 Т. Мэнци, Внешнеполитические интересы РФ и КНР: перспективы сблинения, Петербург 2017, s. 53.

14 Rosyjskie Centrum Eksportu (Российский экспортный центр) to instytucja państwowa wspierająca eksport towarów niesurowcowych, która zapewnia rosyjskim eksporterom szeroki zakres finansowych i niefinansowych środków wsparcia. Współpraca z odpowiednimi ministerstwami i departamentami, a także z kluczowymi branżami i organizacjami biznesowymi pozwala poprawić warunki eksportu w Rosji i wyeliminować wpływ istniejących barier w realizacji zagranicznej działalności gospodarczej.

15 А. ААрианова, А. Медецкий, Россия рассчитьъвает на бум продуктового экспорта в Китай, https://rueconomics.ru/226007-rossiya-rasschityvaet-na-bum-produktovogo-eksporta-vkitai\#from_copy (dostęp: 10.04.2018).

16 Ю. Кулинцев, Российско-китайские отношения: Хроника II кв. 2016 - I кв. 2017 http://russiancouncil.ru/russia-china-2017bilateral\#trade (dostęp: 11.04.2018). 
w czerwcu 2016 r. Podpisano ponad 30 dokumentów dotyczących współpracy w sferze gospodarki i handlu, infrastruktury, technologii i innowacji, rolnictwa, finansów, energii, mediów, Internetu i sportu. We wspólnym oświadczeniu przywódcy obu państw - Władimir Putin i Xi Jinping po raz pierwszy wypowiedzieli się na szczeblu międzynarodowym na temat potrzeby koordynacji wysiłków na rzecz utrzymania bezpieczeństwa informacji i wezwali społeczność światową do stworzenia nowego porządku w globalnej przestrzeni informacyjnej.

Wśród dokumentów podpisanych podczas wizyty Władimira Putina w ChRL jednym z ciekawszych jest umowa o kompleksowej współpracy strategicznej między Rosyjskimi Kolejami (Rossijskije żeleznyje dorogi) a China Railway Corporation. Strony wyraziły gotowość do rozszerzenia współpracy w ramach integracji pasma gospodarczego Nowego Jedwabnego Szlaku i Eurazjatyckiej Unii Gospodarczej. Przedstawiciele Rosji i Chin osobno rozmawiali o budowie linii kolei dużych prędkości Moskwa-Kazań, która jest obecnie projektowana ${ }^{17}$. Przy całkowitym koszcie projektu w wysokości 1 tn rubli strona chińska jest gotowa dać Rosji 400 mld rubli na warunkach kredytowych. Dla Chin oznacza to dalsze umacnianie swej pozycji na międzynarodowym rynku budowy kolei. Dla Rosji natomiast jest to okazja, by stworzyć pierwsze w kraju $700 \mathrm{~km}$ drogi, którą można będzie pokonać w 3,5 godziny, zamiast potrzebnych 11 godzin $^{18}$.

Relacje między Federacją Rosyjską a ChRL mają strategiczne znaczenie w rosyjskiej polityce zagranicznej. Wspomniana wyżej wizyta Putina zbiegła się z 15. rocznica podpisania traktatu o dobrym sąsiedztwie i przyjaznej współpracy między Chinami i Federacją Rosyjską. Spotkanie Władimira Putina i Xi Jinpinga w pełni odzwierciedliło współczesne stosunki rosyjsko-chińskie, które w szybko zmieniającej się sytuacji geopolitycznej na przestrzeni poradzieckiej można scharakteryzować starym rosyjskim przysłowiem: „Bliski sąsiad jest lepszy niż daleki krewny”. Nie bez znaczenia było również spotkanie premierów obu państw w 2017 r. Zeszłoroczne, 22. spotkanie premiera Federacji Rosyjskiej Dmitrija Miedwiediewa z premierem ChRL Li Keqiangiem odbyło się w Pekinie w dniach od 31 października do 2 listopada. Przedstawiciele obu państw brali udział w ceremonii podpisania ponad 20 dokumentów o współpracy: inwestycyjnej, energetycznej, humanitarnej, rolnej, celnej, finansowej oraz związanej z przestrzenią kosmiczna. Wśród najważniejszych znalazło się porozumienie zawarte pomiędzy Vneshekonombank ${ }^{19} \mathrm{i}$ chińskim Exim

17 Совместныле документы, подписанныге в ходе офиииального визита Президента Российской Федерачии В.В. Путина в Китай, http://kremlin.ru/supplement/5101 (dostęp: 11.04.2018).

18 Итоги визита Путина в Китай: нефть, вертолеть, железнаядорога, самолеть, httр://press.rzd. $\mathrm{ru} / \mathrm{smi} / \mathrm{public} / \mathrm{ru}$ ?STRUCTURE_ID=2\&layer_id=5050\&refererLayerId=5049\&id=294123 (dostęp: 11.04.2018).

19 Bank rozwoju (Внешэкономбанк) powstał w celu zwiększenia konkurencyjności gospodarki rosyjskiej, jej dywersyfikacji i stymulacji działalności inwestycyjnej. Nie jest bankiem komercyjnym. 
Bank $^{20} \mathrm{w}$ sprawie kredytu w juanach (wartego 3 mld USD). Pieniądze będą przeznaczone na finansowanie obiektów infrastruktury oraz współczesnych projektów innowacyjnych, realizowanych na terytorium Federacji Rosyjskiej. Ten krok może pomóc Rosji w podwyższeniu produkcji i jakości nowych technologii oraz wesprzeć powstanie w przyszłości specjalnego funduszu finansowego dla technologii i innowacji. Kolejne porozumienie wynegocjowane przez Dmitrija Miedwiediewa i Li Keqianga, które w przyszłości ma ułatwić współpracę handlową, dotyczyło współpracy w ramach zarządzania ryzykiem i zostało podpisane przez Federalną Służbę Celną Rosji i Główną Administrację Celną Chin. Ma ono usprawnić pracę administracji celnych Rosji i Chin, co może wpłynąć na dalszy wzrost obrotu towarowego między tymi krajami.

Jeżeli chodzi o wymianę handlową w sferze niesurowcowej, to rosyjskie Ministerstwo Rolnictwa i chiński Zarząd Generalny Nadzoru Jakości podpisali protokół dotyczący wymagań fitosanitarnych dla pszenicy, owsa, siemienia lnianego i gryki. Są to rozporządzenia w ramach eksportu owych produktów z Rosji do Chin. Oddzielną sferą stosunków rosyjsko-chińskich jest współpraca energetyczna. Jak wyżej wskazano, obejmuje ona aż 50\% całego eksportu rosyjskiego do Chin. Chiński kapitał rozszerza swoją obecność w projektach związanych z dostawą ropy. Przedsiębiorstwo Novatek ${ }^{21}$, największy niepaństwowy producent gazu ziemnego w Rosji, zawarło umowę o strategicznym partnerstwie z CNPC ${ }^{22}$.

Dalszy rozwój relacji gospodarczych między Rosją a Chinami jest możliwy, czego dowodzą wciąż rosnące obroty towarowe między nimi. Chiny są dosyć obszernym rynkiem dla Rosji, na którym rosyjscy partnerzy mogliby realizować produkcję towarów sektora maszynowego i innych gałęzi gospodarki narodowej. Ponadto tak bliskie sąsiedztwo obu państw i obecność wspólnej granicy o długości ponad 4 tys. km obniżają koszty transportowe związane z dostarczeniem towarów, umożliwiają zwiększenie ich konkurencyjności oraz rozszerzenie wzajemnego obrotu towarowego przez kanały handlu przygranicznego. Wreszcie, coraz częstsze spotkania liderów obu państw i coraz większa liczba podpisywanych umów i porozumień praktycznie w każdej sferze gospodarczej wskazują na silne powiązania polityczne oraz przyjazne relacje między krajami. Biorąc pod uwagę tendencje rozwoju globalnego oraz charakter relacji Rosji z Zachodem, można prognozować, że w przyszłości

\footnotetext{
${ }^{20}$ China Exim Bank (Export-Import Bank of China) - jeden z trzech instytucjonalnych banków w Chinach, założony w celu implementacji polityki państwowej w przemyśle, handlu zagranicznym, gospodarce i finansach. Jego celem nadrzędnym jest promocja chińskich produktów i usług, szczególnie w segmencie elektroniki i wyrobów high-tech. Finansuje dużą część inwestycji chińskich na terenie Azji, Afryki i Ameryki Lacińskiej.

${ }^{21}$ Novatek (Новатэк) - rosyjski producent gazu ziemnego, założony w obwodzie samarskim w $1994 \mathrm{r}$.

22 22-я регулярная встреча глав правительств России и Китая, https://minvr.ru/press-center/ news/9548/ (dostęp: 11.04.2018).
} 
rosyjsko-chińskie stosunki zachowają obecną drogę rozwoju i będą kontynuować strategiczną politykę partnerstwa. W tej sytuacji najważniejszym zadaniem Rosji jest poszerzanie biznesowych kręgów z chińskimi partnerami i pogłębianie poziomu obustronnego współdziałania w sferach handlu, finansowania i innowacji.

\section{SUMMARY}

\section{NEW DEVELOPMENT PERSPECTIVES IN RUSSIAN-CHINESE ECONOMIC RELATIONS}

After the incidents in 2014, sanctions proved to be an important impulse to cool the relations between Russia and the West. This paper relates to new perspectives in economic relations between Russia and China. The following were explained: the dynamics of trade in raw materials and non-energy products as well as actions taken by the Russian and Chinese authorities to improve the processes taking place in cooperation between these two countries in the years 2016 and 2017. 